\title{
Morphological Characteristics and Chemical Composition of Flesh and Haemolymph of Snails Fed Compounded Diet using Quail Droppings Meal as Protein Source
}

\author{
Nasir Olaniyi Ilelaboye ${ }^{1 *}$, Ede Dorathy Amuche ${ }^{2}$ and Iwunze Nnaemeka² \\ ${ }^{1}$ Department of Science Laboratory Technology, The Federal Polytechnic Ilaro \\ Ogun State, Nigeria \\ ${ }^{2}$ Department of Science Laboratory Technology, Redeemer's College of Technology and Management Mowe \\ Ogun State, Nigeria \\ *Corresponding author's email: nasir.ilelaboye [AT] federalpolyilaro.edu.ng
}

\begin{abstract}
This study investigated the morphological characteristics, and chemical composition of Archachatina marginata (African Giant Land Snail) reared on Quail droppings meal (QDM.) substituted for protein sources in snail feed. Five trial snail feeds (Diet I-V) were fed to fifty snails (average weight $157.3 \mathrm{~g}$ ) for 12 weeks. The morphological characteristics of the snail and its flesh and haemolymph chemical composition were determined using standard methods. There was an appreciable increase in the growth parameters (weight, shell width and shell length) across the treatment groups. The feed conversion ratio (FCR) ranges from 2.74 to 3.75, and snails served Diet I gave the highest FCR. The result of the proximate analysis revealed that snail flesh possessed a higher amount of protein, fat, ash, fibre and energy except carbohydrate than hemolymph. Increasing QDM in the diets increased the proximate contents of the snail's flesh and hemolymph, except fat and fibre. The minerals found in all the treatments are not toxic, and snails fed diet $V$ possessed the highest mineral contents (sodium, potassium, calcium, magnesium, iron and phosphorus). The result showed that diet $V$ resulted in the best morphological parameters and feed utilisation of A. marginata snail. Substituting protein sources with QDM in snail feed improved the nutritional quality of snails, reducing the cost of the compounded ration.
\end{abstract}

Keywords--- Archachatina marginata, feed conversion ratio, haemolymph. quail droppings meal

\section{INTRODUCTION}

Snails are the foremost collections of Mollusca, representing the largest animal group after arthropods[1]. Snail meat is nutritious and a good source of protein apart from the conventional sources of protein, mainly meat and fish. It also has low lipid content and saturated fatty acids and is rich in iron [2,3]. Due to its nutritional benefits and healthy prospects, there is a rapid increase in the consumption of snail meat since people are being advised against the consumption of red meat due to perceived health reasons. Snail haemolymph (snail blood) is made up of water, organic compounds (hormones, carbohydrates, proteins and lipids), and inorganic salts (magnesium, calcium, sodium, potassium, chlorides, etc.). This liquid functions as a nutrients carrier, thermoregulation, ionic balance, and $\mathrm{pH}$ regulator. The colourless to bluish colour haemolymph can serve as an alternative medicine for high blood pressure, ulcer and asthma, kidney diseases, tuberculosis, anaemia $[4,5]$

African Giant Land Snail is regarded as one of Africa's highly consumed snail species, especially Nigeria, due to its nutritious meaty flesh and its haemolymph health benefit. As healthy as snail meat is, human habitation, indiscriminate hunting and deforestation drastically reduce and destroy snails' habitat. Based on the nutritional and tremendous medical properties of snails, the consumption rate of snails is rising, thus, led to an increase in snail farming. Rearing this snail species (Archachatina marginata) and other meaty species will help conserve and ensure their survival. However, the routinely encountered problem in snail rearing is the selection of feed to keep this animal alive and meet its nutritional need. Focusing attention on protein may solve this problem. It plays a crucial role in animal well-being, such as growth, maintenance, repair of tissues, proper metabolism and other enzymatic activities. This study aimed to examine the growth performance, the nutritional content of meat and haemolymph of Snail fed with compounded feed using Quail droppings meal as a substitute for protein sources. 


\subsection{Study Location and Sampling}

\section{METHODOLOGY}

The research was done in the Department of Science Laboratory Technology, Federal Polytechnic Ilaro, Ogun State, Nigeria. Ilaro is a town in Nigeria, positioned at a North latitude of $6.89^{\circ}$, East longitude of $3.02^{\circ}$ and altitude of $68 \mathrm{~m}$. Ilaro ambient temperature ranges between an average of $23^{\circ} \mathrm{C}$ to $34.2^{\circ} \mathrm{C}$. Quail droppings were obtained from Boye's Farm in Ilaro. The quail droppings were sun-dried and followed by removal stones and other foreign materials. After drying, the droppings were milled using a hammer mill to make quail dropping meal (QDM) of $2 \mathrm{~mm}$ particle size.

\subsection{Experimental Snails and Treatments}

The snails used for the study are A. maginata. Fifty (50) pieces of snail (average weight of $153.7 \mathrm{~g}$ ) were purchased from Boye's farm between November and December 2018 and transported to the animal house. A Snail cage with holes to enable free flow of air and proper drainage was built and filled with heat sterilised loamy soil to about $6 \mathrm{~cm}$, and dried almond fruit leaves was placed over the soil to serve as mulch for the snails. Each compartment contained five snails, and their environment was kept moist by spraying water on the snail twice daily. The snails were given the trial feeds daily between 4.00 and $6.00 \mathrm{pm}$ for 12 weeks because snails being nocturnal animals, eat mostly at night [6]. The leftover feed and snails' excreta were removed from the cage every day to prevent pathogens buildup.

\subsection{Experimental Diets}

Four experimental snail diets (Diets II-V) were compounded using quail dropping meal (QDM) at different levels as a protein source to contain at least $20 \%$ crude protein (Table 1). Diet I, which is a modified feed formulation of [7], served as the control.

Table 1. Experimental diets' composition

\begin{tabular}{|l|l|l|l|l|l|}
\hline INGREDIENTS & DIET I & DIET II & DIET III & DIET IV & DIET V \\
\hline Maize & 31.5 & 31.5 & 31.5 & 31.5 & 31.5 \\
\hline Protein source & 64.8 & 47.8 & 30.55 & 13.3 & \\
Bone meal & 1.20 & 1.20 & 1.20 & 1.20 & 1.20 \\
Limestone & 2.25 & 2.25 & 2.25 & 2.25 & 2.25 \\
\hline Quail droppings & & 17 & 34.25 & 51.5 & 64.8 \\
\hline & 100 & 100 & 100 & 100 & 100 \\
\hline
\end{tabular}

Plastic feeders and drinkers were provided for the snail, and $15.0 \mathrm{~g}$ of the experimental Diet was fed to the snails per day every evening for 12 weeks. The daily feed intake is the difference between the initial weight of feed and that of leftover.

\subsection{Data collection}

Data such as the snail weight and the length were taken twice a week, i.e. Mondays and Thursdays. Three snails from each compartment were marked for data collection. The morphological parameters of the snails were measured every week. Bodyweight was taken using a weighing balance (Camry electronic kitchen scale model EK 5350. 0.1g), shell length and shell width were measured with Vernier callipers, and feed conversion ratio was calculated.

\subsection{Chemical Analysis}

The three marked snails from each treatment were sacrificed by breaking the apex to enable haemolymph collection and the meat processed into fine powder. Proximate composition determination was done using standard AOAC methods [8]. The mineral analysis was carried out on the remaining portion using Atomic Absorption Spectroscopy (AAS), after digestion using Hydrochloric acid and Nitric acid

\subsection{Statistical Analysis}

The data collected were subjected to One-way analysis of variance (ANOVA) in a Completely Randomised Design. Treatment means were separated using Duncan Multiple Range Test at 5\% probability level, using the Statistical Package for Social Sciences (SPSS.) Version 17.0.[9] 


\section{RESULTS AND DISCUSSION}

\subsection{Proximate composition and mineral composition of the diets}

Table 2: Proximate composition (\% DM) and Mineral composition (mg/100g) of the experimental diets

\begin{tabular}{|l|l|l|l|l|l|}
\hline parameters & Diet I & Diet II & Diet III & Diet IV & Diet V \\
\hline Proximate & & & & & \\
\hline moisture & $10.80^{\mathrm{ab}} \pm .28$ & $10.70^{\mathrm{a}} \pm .07$ & $10.67^{\mathrm{a}} \pm .16$ & $10.89^{\mathrm{a}} \mathrm{b} \pm .09$ & $11.17^{\mathrm{b}} \pm .08$ \\
\hline protein & $26.42^{\mathrm{a}} \pm 1.17$ & $29.22^{\mathrm{b}} \pm 08$ & $31.44^{\mathrm{c}} \pm .13$ & $32.58^{\mathrm{c}} \pm .06$ & $34.49^{\mathrm{d}} \pm .09$ \\
\hline fat & $4.02^{\mathrm{c}} \pm .16$ & $3.51^{\mathrm{c}} \pm .08$ & $3.37^{\mathrm{b}} \pm .14$ & $3.24^{\mathrm{b}} \pm .06$ & $2.82^{\mathrm{a}} \pm .10$ \\
\hline fibre & $5.39^{\mathrm{a}} \pm .38$ & $6.37^{\mathrm{b}} \pm .07$ & $7.85^{\mathrm{c}} \pm .14$ & $8.85^{\mathrm{d}} \pm .14$ & $10.31^{\mathrm{e}} \pm .11$ \\
\hline ash & $9.01^{\mathrm{a}} \pm .74$ & $10.52^{\mathrm{b}} \pm .07$ & $11.71^{\mathrm{c}} \pm .15$ & $13.43^{\mathrm{d}} \pm .09$ & $15.23^{\mathrm{e}} \pm .01$ \\
\hline Carbohydrate & $44.37^{\mathrm{a}} \pm .71$ & $39.68^{\mathrm{b}} \pm .04$ & $34.96^{\mathrm{c}} \pm .13$ & $31.02^{\mathrm{d}} \pm .15$ & $25.99^{\mathrm{e}} \pm .03$ \\
\hline Energy & $313.96^{\mathrm{c}} \pm 10.84$ & $312.51^{\mathrm{c}} \pm 6.27$ & $295.91^{\mathrm{b}} \pm 1.31$ & $283.55^{\mathrm{b}} \pm .87$ & $267.28^{\mathrm{a}} \pm .64$ \\
\hline Minerals & & & & & \\
\hline Sodium & $484.58^{\mathrm{a}} \pm .59$ & $525.37^{\mathrm{b}} \pm .87$ & $584.22^{\mathrm{c}} \pm .40$ & $622.45^{\mathrm{d}} \pm 1.07$ & $683.24^{\mathrm{e}} \pm 1.08$ \\
\hline Potassium & $831.69^{\mathrm{a}} \pm .44$ & $901.20^{\mathrm{b}} \pm 1.34$ & $969.98^{\mathrm{c}} \pm 7.4$ & $1041.85^{\mathrm{d}} \pm .49$ & $1105.85^{\mathrm{e}} \pm 1.20$ \\
\hline Calcium & $65.07^{\mathrm{a}} \pm .66$ & $69.58^{\mathrm{b}} \pm .95$ & $87.57^{\mathrm{c}} \pm 1.09$ & $95.71^{\mathrm{d}} \pm .27$ & $108.51^{\mathrm{e}} \pm .69$ \\
\hline Magnesium & $6.15 \pm 1.10$ & $6.32 \pm .60$ & $7.19 \pm .38$ & $7.57 \pm .20$ & $7.97 \pm .91$ \\
\hline Iron & $84.60^{\mathrm{a}} \pm .40$ & $89.80^{\mathrm{b}} \pm .46$ & $97.36^{\mathrm{c}} \pm .44$ & $104.57^{\mathrm{d}} \pm .71$ & $112.09^{\mathrm{e}} \pm .49$ \\
\hline Phosphorus & $21.43^{\mathrm{a}} \pm .18$ & $21.74^{\mathrm{a}} \pm .44$ & $26.10^{\mathrm{b}} \pm .42$ & $28.36^{\mathrm{c}} \pm .20$ & $29.58^{\mathrm{c}} \pm .1 .03$ \\
\hline
\end{tabular}

Different superscripts on mean values in the same row indicate significant differences $(\mathrm{P}<0.05)$.

As shown in Table 2, the proximate composition of the trial differs significantly $(\mathrm{P}<0.05)$. Diet V (100\% QDM) possessed the highest crude protein, fibre and ash concentration, while Diet I had the highest carbohydrate, fat concentration and derivable crude energy. Also, the mineral analysis results revealed a significant difference $(\mathrm{P}<0.05)$ in all the mineral concentrations analysed except magnesium of all the experimental diets, and diet $\mathrm{V}$ mineral content was the highest. At the same time, Diet I had the lowest mineral concentration. (Table 2).

\subsection{Morphological parameters}

Table 3: Growth response and feed utilisation of the snails

\begin{tabular}{|l|l|l|l|l|l||}
\hline Growth parameters & DIET I & DIET II & DIET III & \multicolumn{1}{|c|}{ DIET IV } & DIET V \\
\hline Initial weight $(\mathrm{g})$ & $153.95 \pm 5.16$ & $154.15 \pm 4.45$ & $149.30 \pm 8.49$ & $159.95 \pm 2.33$ & $162.93 \pm 6.19$ \\
\hline Final weight $(\mathrm{g})$ & $218.23 \pm 5.13$ & $218.95 \pm 4.10$ & $215.54 \pm 9.54$ & $226.71 \pm 3.38$ & $237.38 \pm 15.38$ \\
\hline Weight gain $(\mathrm{g})$ & $64.28^{\mathrm{a}} \pm .04$ & $64.80^{\mathrm{a}} \pm .35$ & $66.24^{\mathrm{a}} \pm 1.05$ & $66.76^{\mathrm{a}} \pm 1.05$ & $75.45^{\mathrm{b}} \pm 9.19$ \\
\hline Initial width $(\mathrm{cm})$ & $50.80 \pm .00$ & $51.45 \pm 1.41$ & $51.90 \pm 2.26$ & $52.48 \pm .25$ & $54.00 \pm 2.83$ \\
\hline Final width $(\mathrm{cm})$ & $68.58 \pm .00$ & $69.46 \pm 1.91$ & $70.07 \pm 3.05$ & $70.84 \pm .33$ & $72.90 \pm 3.82$ \\
\hline Width gain $(\mathrm{cm})$ & $17.78 \pm .00$ & $18.01 \pm .49$ & $18.17 \pm .79$ & $18.37 \pm .09$ & $18.90 \pm .99$ \\
\hline Initial length(cm) & $104.73^{\mathrm{b}} \pm .81$ & $102.45^{\mathrm{ab}} \pm 1.34$ & $101.10^{\mathrm{a}} \pm .42$ & $103.25^{\mathrm{ab}} \pm 1.20$ & $104.53^{\mathrm{b}} \pm .32$ \\
\hline Final length $(\mathrm{cm})$ & $147.66^{\mathrm{b}} \pm 1.15$ & $144.45^{\mathrm{ab}} \pm 1.89$ & $142.55^{\mathrm{a}} \pm .60$ & $145.58^{\mathrm{ab} \pm 1.69}$ & $147.38^{\mathrm{b}} \pm .45$ \\
\hline Length gain $(\mathrm{cm})$ & $42.94^{\mathrm{b}} \pm .33$ & $42.00^{\mathrm{ab}} \pm .55$ & $41.45^{\mathrm{a}} \pm .17$ & $42.33^{\mathrm{ab}} \pm .49$ & $42.86^{\mathrm{b}} \pm .13$ \\
\hline Feed intake $(\mathrm{g})$ & $181.50^{\mathrm{a}} \pm 6.36$ & $182.75^{\mathrm{a}} \pm 3.18$ & $204.50^{\mathrm{b}} \pm 12.02$ & $193.75^{\mathrm{ab}} \pm 1.77$ & $245.50^{\mathrm{c}} \pm .00$ \\
\hline FCR & $2.82^{\mathrm{a}} \pm .00$ & $2.82^{\mathrm{a}} \pm .01$ & $3.09^{\mathrm{b}} \pm .00$ & $2.90^{\mathrm{ab}_{ \pm} \pm .01}$ & $3.25^{\mathrm{c}} \pm .00$ \\
\hline & & & & & \\
\hline
\end{tabular}

Different superscripts on mean values in the same row indicate significant differences $(\mathrm{P}<0.05)$.

The trial feeds were well accepted and consumed by the snails, and as depicted in Table 3, no definite pattern was observed in the level of feeding by the snails as the level of inclusion of QDM increases. The highest feed intake (245.50 g) was observed in snails fed Diet V, and the lowest feed intake $(181.50 \mathrm{~g})$ was observed in those provided Diet I. A reduction in feed consumption was observed from week five, confirming $[7,10]$ findings that snails prefer new food to accustomed 
food. The results revealed a significant difference in the FCR. as the addition of QDM increases, ranging from Diet II (2.74) to Diet V (3.75). There was an appreciable but not significant weight gain difference between the experimental snails fed on Diet I- IV; however, snails fed Diet V differed significantly (75.45 g). The result agrees with the claim of [11]that protein concentration and energy level in the diets influenced the weight gain and feed efficiency of the snail. The shell length gain in the experimental snails varied significantly. There was a remarkable increase in shell width gain by the experimental snails as the amount of QDM increases in the diets. Snails fed on Diet V $(18.90 \mathrm{~cm})$ had the highest gain, while those reared on Diet I $(17.78 \mathrm{~cm})$ had the lowest gain. The observation confirmed the findings of [7] on the effect of poultry droppings on shell length, width and weight of snails because snail possesses the ability to convert nitrogen content of animal dropping to proteins, which have an appreciable effect on its length and weight.

\subsection{Proximate Composition of the Snail Flesh}



Figure 1: Proximate composition of flesh and haemolymph of snail

As presented in Figure 1, the proximate composition of the snail flesh and hemolymph showed no significant difference in the moisture content. However, hemolymph has higher moisture ( $93-95 \%$ WM) than flesh (68 - 69 \% WM). Increasing QDM in the diets resulted in a significant increase in the snail's flesh and hemolymph protein contents. Snail's flesh protein contents $(22.3-23.4 \% \mathrm{WM})$ is over ten times that of hemolymph $(1.8-3.0 \% \mathrm{WM})$. The observed rise in protein snail flesh and hemolymph as QDM addition increased confirmed the work of other researchers such as[7, 12] that snails can convert nitrogen content in animal waste into protein. This might have been the reason for the high average weight gain of the snail fed with Diet V. Hence, the inclusion of QDM in the formulation of snail feed will positively influence the snail's growth performance and nutritional value.

Comparing the fat content in experimental snail's meat and hemolymph, the per cent fat deceased in the meat $(2.81-1.62$ $\% \mathrm{WM})$ as the QDM amount increased in the trial feeds, while the reverse occurred in the corresponding hemolymph ( 0.69 $-1.21 \% \mathrm{WM}$ ) as depicted in figure 1. The fat content of the snail flesh recorded in this study is higher than that of snails' meat (0.9-1.5\% WM) reported by [13]. The inclusion of QDM in the diets affects the ash content of the experimental snails' flesh and hemolymph. The experimental snail flesh ash content $(2.83-3.18 \% \mathrm{WM})$ were more than the ash content of 1.35 to $1.44 \%$ reported by [14]. As shown in figure 1, the snail's hemolymph does not possess fibre; however, the flesh per cent fibre significantly decreased as the amount of QDM in the diets increased.

There was a linear increase in the per cent carbohydrate of both snails' flesh (12.2 - 23.6\% WM) and hemolymph (20.4 $27.4 \% \mathrm{WM}$ ), with hemolymph possessing the higher carbohydrate. The carbohydrate content of the snail flesh recorded in this study is higher than the amount (0.86-1.09\%) reported for A. marginata flesh by [15]. The gross energy of the snail's hemolymph varied significantly with the rise in addition of QDM, but the gross energy of the snail's meat was not significantly different $(\mathrm{p}<0.05)$, except for experimental snails reared on Diet III. The observed results were lower than the gross energy $(489.9 \mathrm{kcal} / \mathrm{kg}-604.45 \mathrm{kcal} / \mathrm{kg}$ ) reported for snail's meat reared on pawpaw leaf meal and poultry dropping meal [12] 


\subsection{Mineral composition of flesh and haemolymph of snail}

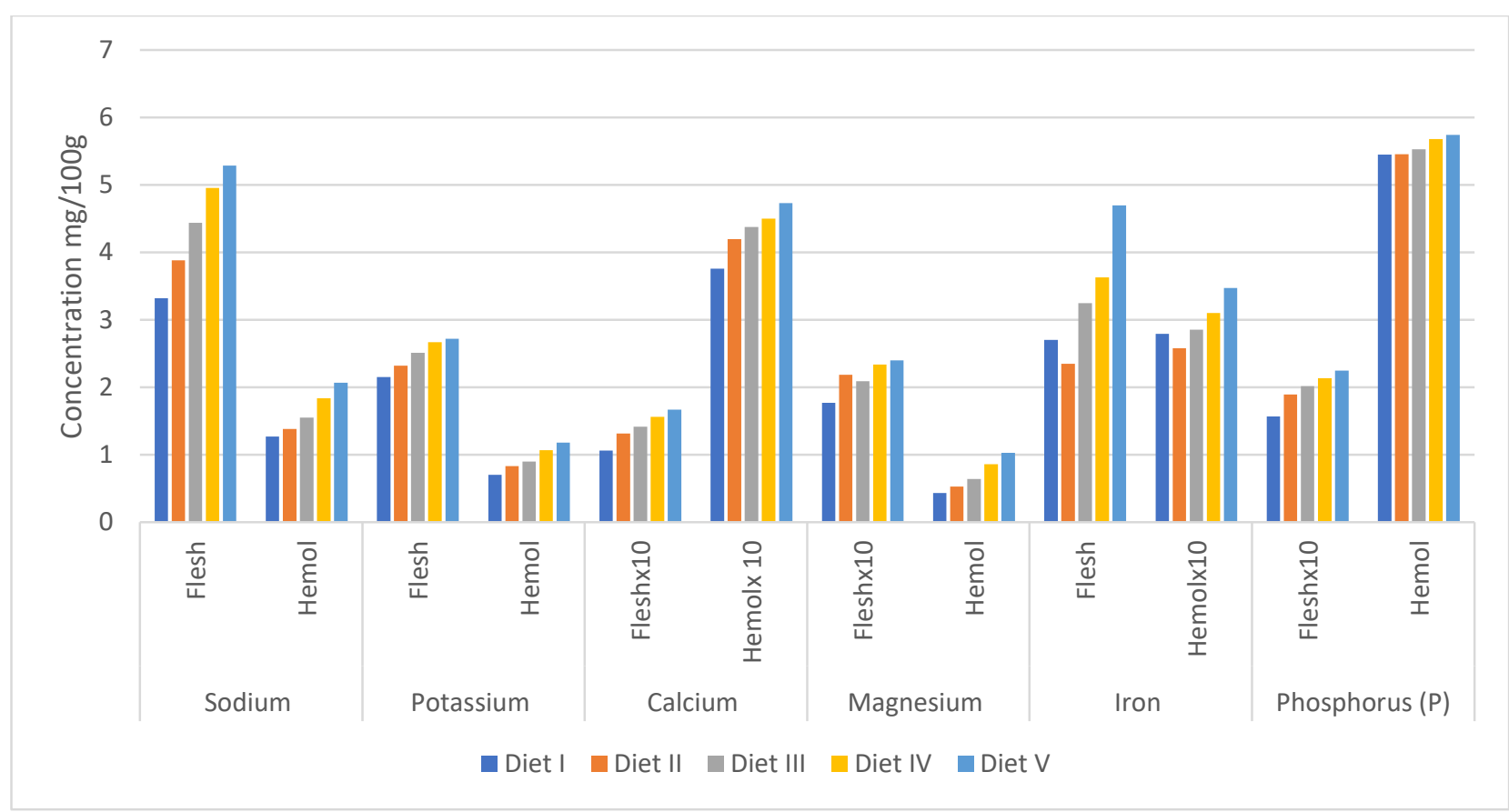

Figure 2: Mineral composition of flesh and haemolymph of snail

The observed results of all the minerals analysis revealed that the snails' meat contain Sodium $(3.23-5.29 \mathrm{mg} / 100 \mathrm{~g})$, Potassium (2.15 - $2.72 \mathrm{mg} / 100 \mathrm{~g})$, Calcium (10.63 - $16.73 \mathrm{mg} / 100 \mathrm{~g})$, Magnesium (17.71 - $24.01 \mathrm{mg} / 100 \mathrm{~g})$, Iron (2.35 $4.70 \mathrm{mg} / 100 \mathrm{~g})$ and Phosphorus $(15.70-22.49 \mathrm{mg} / 100 \mathrm{~g})$, while haemolymph contain Sodium $(1.27-2.07 \mathrm{mg} / 100 \mathrm{~g})$, Potassium (0.7 - $1.18 \mathrm{mg} / 100 \mathrm{~g})$, Calcium (37.6 - $47.3 \mathrm{mg} / 100 \mathrm{~g})$, Magnesium (0.43 - $1.03 \mathrm{mg} / 100 \mathrm{~g})$, Iron (27.98 -34.71 $\mathrm{mg} / 100 \mathrm{~g})$ and Phosphorus $(5.45-5.75 \mathrm{mg} / 100 \mathrm{~g})$. These mineral elements rose significantly $(\mathrm{P}<0.05)$ in both the flesh and the haemolymph as levels of inclusion of QDM in the diets increased (Figure 2). However, the flesh possesses more minerals, except calcium and iron, than the haemolymph. In confirmation of [16] findings that any physiological process happening in snail's body is replicated in the haemolymph being the fluid that bath snails, the above results revealed that snail's haemolymph mineral content exhibited the same trend as snail's body mineral content.

Both snail meat and haemolymph are rich in calcium, which is required to form bones and teeth; therefore, its deficiency can cause bones deformation. Calcium ions are necessary for the effective working of nerves and muscles and blood clotting [17]. Hence, the calcium level and blood clotting process can be improved by the consumption of snails. Magnesium and Phosphorous, like calcium, are also required in the formation of bones and teeth. Compared with other animals, these minerals were generally low in snails and, therefore, can not serve as a good source [17].

The highest iron concentration in this experiment was obtained in snail haemolymph, and this agreed with the findings of $[7,16]$ that iron is more abundant in the haemolymph. Iron is an integral part of the blood which attracts oxygen for cellular oxidation of anaemia, and the availability of other essential minerals like calcium, magnesium and zinc in snails may justify the drinking of snails' haemolymph by pregnant women and for traditional treatment of hypertension[5, 14, 18].

\section{CONCLUSION}

Quail Droppings Meal (QDM), as clearly stated in the present study results, has no detrimental effects on the nutritional quality of snail meat. Its uses as a replacement for other expensive protein sources such as Soybean meal, Groundnut cake, cottonseed cake etc., should be encouraged in formulating diets for snails. The highest inclusion level used in this study helps raise the snail meat's nutrient contents above the control group. It's cheap, simple to process, and valuable protein features make it a good source of protein in snail feed.

\section{REFERENCES}

1.. Emelue, G., \& Dododawa, Z. (2017). Nutritional Composition of African Giant Land Snail (Archachatinamarginata) Fed on Diet from Different Protein Sources. Journal of Agriculture and Ecology Research International, 13(1), 1-7. https://doi.org/10.9734/JAERI/2017/33927

2. Ademosun, A.A. Omidiji, M.O. (1999) The Nutrient value of African giant land snail (Archachatina marginata) Journal of Animal Protection Research 8 (2): 876-877. 
3. Orisawuyi YA (1989). Practices guide to snails rearing. Gratitude Enterprises, Lagos, p. 27.

4. Idowu, R. T., Inyang N. M, And Eyo, J. E. (2004).The physical-chemical parameters of an African Arid Zone manmade Lake. Animal Research International. 1(2): 113 - 119

5. Omole, A.J., 2002. Nutrients requirements for different stages of growth of African giant Snail (Archachatinamarginata) PhD thesis submitted at the dept of animal science, University of Ibadan.

$\mathrm{P} 2$

6. Cobbinah, J.R., Vink, A. and Onwuka B., (2008). Snail Farming: Production, Processing and Marketing, (Agromisia Foundation, Agrodok 47 and CTA, Wageningen.)

7. Ademolu K.O, Idowu A.B, Mafiana C.F, Osinowo O.A (2004). Performance Proximate and Mineral Analyses of African Giant Land Snail (Archachatina marginata) Fed Different Nitrogenous Sources; Afr. J. of Biomech. 3(8): 412 417.

8. AOAC, (2006) Official methods of analysis of association of official analytical chemists, 18th Edition;

9. SPSS 2007 Statistical Package for the Social Sciences for Windows, Version 17.0, Chicago, SPSS. Inc.;

10. South A (1992). Terrestrial slugs: Biology, ecology and control. Chapman and Hall, pp. 66 -101.

11. Onimisi P A and Omage J J (2006) Evaluation of poultry litter as a feedstuff for growing rabbits LivestockResearch for Rural Development $18(11)$

12. Ilelaboye N. O. and O. O. Adegbola, 2018 Growth Performance and Proximate Composition of Archachatina marginata Snail Fed with Formulated Diets Using Pawpaw (Carcia papaya) Leaf Meal and Poultry Droppings Meal as Protein Sources Journal of Agriculture and Ecology Research International 16(1): 1-10. https://doi.org/10.9734/JAERI/2018/43922

13. Kalio G.A. And I. Etela, 2011 Nutritional And Sensory Profiling Of The African Giant Land Snail Fed CommercialType And Leaf-Based Diets In A Rain-Forest Ecology. African Journal of Food, Agriculture, Nutrition and Development $11(5)$

14. Fagbuaro O., Oso J. A., Edward J. B. and R.F. Ogunleye 2006. Nutritional status of four species of giant land snail in Nigeria. J. Zhejiang Univ. Sci. B., 2006; 7: 686-689.

15 Bamidele, J. A., Ademolu, K. O., Idowu, A.B., Aladesida, A. A. and Oladele, A. O. (2018) Biochemical and Nutritional Composition of Giant African Land Snail (Archachatina marginata) from Southwest Nigeria Pertanika J. Trop. Agric. Sci. 41 (1): 129 - 138

16. Akinloye, O.A. and O. Olorede., 2000. Effects of different feeding conditions on performance, haemolymph biochemical and mineral value of Giant African snail (Archachatina marginata), Journal of Agriculture and Environment 1:143-147

17. Babalola, O. O., \& Akinsoyinu A. O. (2009). Proximate composition and mineral profile of snail meat from different breeds of land snail in Nigeria. Pakistan Journal of Nutrition, 8(12), 1842-1844.

18. Kehinde, Adelakun, Halide, Babatunde And Fadimu (2020). Biochemical evaluation of meat and haemolymph of African Land Snail (Archachatina marginata, Swainson) in South-west Nigeria Egyptian j. Anim. Prod. 57(3):121-126 https://ejap.journals.ekb.eg 